\title{
Instructional design in foreign language teaching
}

\author{
Anna Viktorovna Palkova* and Larisa Mikhailovna Sapozhnikova \\ Tver State University, Faculty of Foreign Languages and International Communication, Department \\ of German Language, Tver, Russia
}

\begin{abstract}
This paper offers a presentation of two original multimedia educational resources with interactive online tasks in the German language developed within the course "Teacher's and translator's electronic resource" in cooperation with the students of the Faculty of Foreign Languages and International Communication of Tver State University. The purpose of our projects assumes, in the first place, deliberate formation of a learning environment meeting the needs of a target audience. In the process of working over the projects, the authors took into consideration the principles of instructional design that served as a theoretical basis for the development of educational materials. Instructional design is viewed by the authors of the article as a separate branch of practical pedagogy which primarily focuses on the application of pedagogical knowledge in practice, namely, development of high-quality efficient educational resources with the use of modern information technologies. The distinctive feature of the theory of instructional design is consideration of not so much the cognitive parameters and mental processes characterising the learning process as the efficient methods and learning formats stimulating these cognitive processes. The most important result of our work is the conclusion that the projects developed with regard for the principles of instructional design under the ADDIE model contribute to enhancement of students' cognitive abilities and increase the amount and quality of information assimilated by them; at the same time, the learning becomes more systemic and practice-oriented from the first stages of project analysis and planning. The novelty of our approach specifically lies in practical treatment of instructional design as a tool for development of learning materials, invigoration of learning activities and tutor support of students.
\end{abstract}

Keywords: e-learning, online-project, foreign language teaching, instructional design, ADDIE model

\section{Introduction}

This article dwells on applying the principles of instructional design (ID) in the process of development of educational resources for the study of foreign languages. The authors would like to present two multimedia educational resources with interactive online

*Corresponding author: Palkova.AV@.tversu.ru 
assignments in the German language, developed within the course "Teacher's and translator's electronic resource" for the students of the Faculty of Foreign Languages and International Communication of Tver State University.

The first online project "Alexander von Humboldt: das Multitalent" [1] was developed in the process of participation in the All-Russian Marathon of Endeavours for German Language Learners 2019 "Travel and Explore: Creating the Future with Alexander von Humboldt", held by the Interregional Association of German Language Teachers (MAUPN) and supported by the Goethe German Cultural Centre in Russia (Goethe-Institut). The project is dedicated to the $250^{\text {th }}$ anniversary of the famous German scientist, to be implemented in the field of natural sciences and for popularisation of the German language as a tool for obtaining and presentation of scientific knowledge.

The second online-project "Osnabrück - Tver: 30 Jahre Partnerschaft" [2] is devoted to German-Russian municipal and regional cooperation. The project was included in the competition held within the framework of the Year of Germany in Russia. The project partner from the German side is the Twin Cities Partnership Office. The partner from the Russian side is Department for Education of Tver City Administration.

While working over the projects, the authors took into account the ID principles that served as a theoretical basis for the development of training materials. In the first place, the authors drew upon the fundamental research by such scholars as: Gagne et al. [3], Briggs et al. [4], Merrill \& Twitchell [5], Merrill [6], Reigeluth et al. [7], Glaser [8], Smith \& Ragan [9], and Sweller [10]. Particular attention was paid to application of ID in higher education: Bain [11], Gagne \& Grimaldi [12], and Mancilla \& Frey [13].

The presented projects have two principal goals. First, this is development of educational online content for high-school and college students learning German as a foreign language. The second goal is introducing the basic principles of ID to future foreign language teachers, along with instrumental online platforms for the development of interactive exercises. This practice-oriented approach accounts for the novelty of the present research.

It was hypothesised that the development of foreign language learning materials based on ID principles under the ADDIE model is the most efficient and convenient way to master the basics of instrumental design and to create innovative electronic educational resources. The prerequisite for choosing this particular approach was the well-defined structure and the transparent development plan compiled for such educational resources.

\section{$2 \quad$ Materials and methods}

The development of our projects is based on the analysis and synthesis as theoretical methods of scientific research. In accordance with the instructional design model ADDIE [14], the staging ground for working on educational projects is the analysis of the target audience, its needs and learning objectives. Subsequently, the learning content and interactive exercises are synthesised on the basis of the received and analysed information for the formation of required competencies. "ADDIE" means an English-language acronym based on 5 phases of project development: Analysis, Design, Development, Implementation, Evaluation [15].

The definitions of instructional design are numerous. Briggs understands instructional design as "a holistic process of analysing learning needs and goals along with the development of a system of methods for conveying due knowledge to meet these needs" (cited by [15]). In the authors' opinion, the best approach is treatment of instructional design as "a systemic approach to the development of a learning process, based on the 
academic course content, specifics of style and sequence of material presentation, as well as the ways of its presentation" [16]. Instructional design may be considered as a theory (science) and practice. The authors deem the practical approach to be more relevant, since it involves designing and development of effective educational environment with the use of modern information and communication technologies. At the same time, the concept of instructional design makes it possible to enhance independent learning activity. Moiseeva et al. [17] rightly note that the English term "instructional design" originally meant "development, design of instruction manuals", whereas nowadays it is extended to "learning activities design" where the tutor's function of instructor and the students" independent work are deemed to be of paramount importance.

Takushevich considers instructional design as a separate branch of practical pedagogy [18]. Abyzova emphasises that instructional design is "a scientifically grounded process based on the achievements of such scholarly fields as pedagogy, psychology, ergonomics, aesthetics, design, informatics, economy", which process is relevant "in terms of the modern education reform: upon transition from the knowledge-based paradigm to the competence-based one, with intensification and informatisation of the modern training practices" [19]. Currently, the most urgent challenge in the sphere of instructional design is the development of high-quality efficient methods of distance learning with the use of information technologies.

\section{$3 \quad$ Results}

In designing the projects, the authors proceeded from the basic principles of instructional design according to Gagne et al. [3]. The authors made an effort to match their own training materials with the learners' needs and to present them in a web-quest format attractive for the target audience to be covered by the developed educational projects - high-school and college students. The new information is accompanied by numerous interactive test assignments of different types. The educational web-quests represent complex learning projects methodologically prepared by the teacher, that involve authentic Internet resources contributing to independent and partially autonomous learning.

When developing and implementing the projects, three elements of instructional design meeting Reinmann's "instrumental concept" [20] were taken into account:

- material aspect of training: supply of educational material;

- $\quad$ procedural aspect of training: intensifying the learning process;

- $\quad$ social aspect of training: learners' support.

According to this concept, instructional design is deemed, in the first place, as a tool to create and design learning materials. It was important for the authors to find relevant information on selected topics, so that the students could concentrate on the learning content.

Second, instructional design is treated as a tool for development of training assignments. This is an intensification phase of the learning process. In order to increase the students' intrinsic motivation, the authors compiled a number of interesting tasks using the online platform LearningApps.org. Different types of interactive tasks were chosen: quizzes, memorials, pairs, time feed, interactive videos, etc. The Osnabrück-Tver project envisages two levels of complexity: A2-B1 with 10 tasks and B2-C1 with 20 tasks, partially with higher complexity. This makes it possible to achieve the required learning outcomes in different groups of students.

Third, instructional design is used as a tool to support the learning process. Despite the opportunity of independent work over the tasks during the project, a number of webinars 
were held to answer the students' questions. Some assignments were resolved collaboratively; the students having higher level of language proficiency helped the students with lower proficiency. Meanwhile, competitive tactics were chosen for other groups. This individualised approach to students and groups was justified - the project participants proved to be satisfied. In addition, particular guidelines were developed for the teachers and tutors who were supposed to hold such web-quests for their students in the future.

So far, the projects have been successfully implemented in several groups at the Department of Foreign Languages and International Communication of Tver State University. The participants were represented by students studying German as a first and second foreign language, as well as a group of high school students of Tver Lyceum studying German as a second foreign language. It is also envisaged to implement the projects for the students and senior schoolchildren of Osnabrück within the framework of the city-twinning programme. The realisation of the projects demonstrated success and efficiency of the chosen methodology for the development of learning materials, as evidenced by the feedback on the part of the students and their teachers.

The project "Osnabrück - Tver: 30 Years of Partnership" was presented, with the support of Tver State University, at the IV Germany-Russia Youth Forum for Partner Cities (June 2021).

\section{Discussion}

We would like to present, for the discussion of the scientific community, the issue of widespread application of the ID concept in teaching foreign languages and the transformation of the training materials development process under the ADDIE model into a traditional algorithm for creating not just separate training projects, but a developmental digital educational environment in general, where systemic planning comes to the fore along with thorough elaboration of educational materials in accordance with the training objectives and modification of training courses in accordance with current learning results.

It should be emphasised that the development of e-learning resources is a time-consuming and costly process; therefore, proper planning will help to exclude the costs of further modification.

\section{Conclusion}

The article presents online projects in the German language involving particular country studies, developed with regard for the concept of ID, i.e. systemic approach to the construction of learning process according to which the content, methods and organisation of the training process are subordinated to the learning objectives.

We would like to point out that it is the practical approach that is particularly relevant in the context of rapid digitalisation of the sphere of education, since it deals with design and development of efficient educational environment involving the use of modern information and communication technologies. We agree with the opinion of Krechetnikov [21] voicing that "the key goal of instructional design is to create and maintain the educational environment that provides the learner's psychologically comfortable and pedagogically substantiated development on the basis of maximum possible rational presentation, interrelation and combination of different types of educational resources". This view of instructional design opens up interesting prospects for modern pedagogical research. 


\section{References}

1. Online projekt “Alexander von Humboldt: das Multitalent”. Accessed on: October 10, 2020. [Online]. Available: https://bit.ly/3ATBnv1

2. Online projekt “Osnabrück - Tver: 30 Jahre Partnerschaft”. Accessed on: October 10, 2020. [Online]. Available: https://bit.ly/3zSkQq7

3. R.M. Gagne, et al., Principles of instructional design. (Cengage Learning, UK, 2007). https://doi.org/10.1002/pfi.4140440211

4. L.J. Briggs, K.L. Gustafson, M.H. Tillman, Instructional Design, Principles and Application (Educational Technology Publications, Englewood Cliffs, 1993). https://doi.org/10.1002/pfi.4170320312

5. M.D. Merrill, D.G. Twitchell, Instructional design theory (Englewood Cliffs, 1994)

6. M.D. Merrill, Instruc Sci, 29(4), 291-310 (2001). https://doi.org/10.1023/A:1011943808888

7. Ch.M. Reigeluth, B. Beatty, R.D. Myers, Instructional-design theories and models, in Vol. IV: The learner-centered paradigm of education (Routledge, New York, 2016). https://doi.org/10.4324/9781315795478

8. R. Glaser, Edu Measur: Iss Prac, 13(4), 6-8 (1994). https://doi.org/10.1111/j.1745-3992.1994.tb00561.x

9. P.L. Smith, T.J. Ragan, Instructional design (John Wiley \& Sons, New York, 2005). https://doi.org/10.1002/pfi.4170321015

10. J. Sweller, Instructional Design, in T. Shackelford, V. Weekes-Shackelford (eds), Encyclopedia of Evolutionary Psychological Science (Springer, New York, 2018). https://doi.org/10.1007/978-3-319-16999-6_2438-1

11. A. Bain, J App Instr Design, 9(2) (2020). https://dx.doi.org/10.51869/92ab

12. A. Gagné, A. Grimaldi, J App Instr Design, 10(1) (2021). Available: https://edtechbooks.org/jaid $10 \quad 1 /$ designing together.

13. R. Mancilla, B. Frey J App Instr Design, 9(2) (2020). https://dx.doi.org/10.51869/92rmbf

14. S. Kurt, ADDIE Model: Instructional Design (Educational Technology Publications, Englewood Cliffs, 2017)

15. Sovremennoe kursostroenie [Modern Practice of Course Design] (2021). Accessed on: October 10, 2020. [Online]. Available: https://www.lektorium.tv/howtomooc-longread

16. E.V. Tikhomirova, Zhivoe obuchenie: chto takoe elektronnoe obuchenie i kak zastavit ego rabotat [Live Learning: What is E-learning and How to Make It Work] (Alpina Publisher, Moscow, 2016)

17. M.V. Moiseeva, E.S. Polat, M.Y. Bukharkina, M.I. Nezhurina, Internet-obuchenie: Tekhnologii proektirovaniya uchebnykh programm [Internet learning: Technologies of Instructional Design] (Kameron Publishing House, Moscow, 2004)

18. I.A. Takushevich, Man Edu, 2(43), 95-99 (2015). Available: https://cyberleninka.ru/article/n/issledovanie-pedagogicheskogo-dizayna-V-sinhronii-idiahronii

19. E.V. Abyzova, Bul Vyatka State Univ, 3, 12-15 (2010) Available: 
https://cyberleninka.ru/article/n/pedagogicheskiy-dizayn-ponyatie-predmet-osnovnye-k $\underline{\text { ategorii }}$

20. G. Reinmann, Design Studientext Didaktisches [Study text Didactic Design] (Hamburg University, Hamburg, 2015) Available:

https://gabi-reinmann.de/wp-content/uploads/2013/05/Studientext_DD_Sept2015.pdf

21. K.G. Krechetnikov, Soc-Econ Res, Human Jurisp: Theory Prac, 4, 93-97 (2015) Available:

https://cyberleninka.ru/article/n/informatsionnye-tehnologii-pri-smeshannom-obucheni i-v-vuze 